\title{
Identity as Study Object of Positive Psychology
}

\author{
Ana Beatriz Garcia Costa Rodrigues' ${ }^{1}$ Claus Dieter Stobäus², Juan José Mouriño Mosquera ${ }^{3}$ \\ ${ }^{1}$ Postgraduate Program in Education of Pontifical Catholic University of Rio Grande do Sul (PUCRS), Psychology \\ Faculty, Tiradentes University, Aracaju-AL, Brasil \\ ${ }^{2}$ Postgraduate Programs in Education and in Biomedical Gerontology, Pontifical Catholic University of Rio \\ Grande do Sul, Porto Alegre-RS, Brazil \\ ${ }^{3}$ Postgraduate Program in Education, Pro-Rectory of Postgraduate and Research, Pontifical Catholic University \\ of Rio Grande do Sul, Porto Alegre-RS, Brazil \\ Email: stobaus@pucrs.br
}

Received 22 April 2016; accepted 31 May 2016; published 3 June 2016

Copyright (C 2016 by authors and Scientific Research Publishing Inc.

This work is licensed under the Creative Commons Attribution International License (CC BY).

http://creativecommons.org/licenses/by/4.0/

(c) () Open Access

\section{Abstract}

This study aims to list elements for a better understanding and study of identity in the theoretical bias of Positive Psychology. We start from a conception of identity as constitution of the subject, fluid, process, unfinished, constantly building throughout life. It occurs from experiences in certain contexts, the person considering its ontological, social and cultural aspects. Based on Positive Psychology literature review on the subject identity, we find very little published material on this topic in our reality, which leads us to make some links between the constituent elements of the construction of the identity concept in psychology, with the Positive Psychology, among them well-being, self-esteem, self-image and resilience, trying to delineate the possibility of having the identity (more) healthy, a possible object of study in the field of study. The fact that these concepts also are not static and are due to the subject's interactions with the environment in which it develops leads us to consider that this is a plausible way to add healthy identity of the Positive Psychology study objects.

\section{Keywords}

Identity, Positive Psychology, Wellness, Healthy Identity

\section{Introduction}

Positive Psychology implies a more positive vision of human development, especially in Humanities and Health in a more specific way, breaking with the prevailing negative and pathological view in psychology hitherto ex- 
isting in Human and Health Sciences in general because they care more about the disease than with the health of human beings (Seligman, 2004; Paludo \& Koller, 2007).

The focus of the study of this field of psychology is the study of positive emotions, the positive characteristics that have the person, individual and collective institutionally working constructs as quality of life, hope, subjective well-being, self-efficacy, coping strategies and resilience (Pires, Nunes, \& Nunes, 2015).

What can be then is this (more) positive view? It would shift the focus of trying to find and treat diseases and problems with the intention to prioritize skills/abilities that the human being has to self-know themselves better and try to self-held, covering aspects such as happiness, joy, satisfaction, altruism, among others, and seeking to improve their quality of life and achieve even prevent diseases (Seligman, 2004; Paludo \& Koller, 2007).

How to think about constituent elements of identity from the perspective of Positive Psychology? This is the main question of this article. We have realized that there is neither a clearer definition nor many studies in our reality directly facing identity processes, this psychological approach.

However, from a more dialectical and procedural conception of the formation of self-image, self-esteem and self-realization, supported by this theoretical line, and that psychology, in this approach should prioritize the most positive aspects, try to make some links between these concepts within this theoretical perspective and identity, considering the latter as procedural, fluid and constantly changing. Given the above discussed, we will carry on here a healthy identity, towards a healthier identity process.

\section{Identity as Healthier Identity Process}

The identity is related to the constitution of the subject before the world and the circumstances in which it is inserted and acts. To be understood in all its complexity, it is necessary to consider the ontological, cultural and social aspects that act in its constitution, that is, in its identity.

According to Hall (2003), the identity, in a more sociological conception, is the intersection between the personal inner world and the external public. With cultural and institutional changes themselves of what is considered a society in postmodernity, the person is no longer only one in possession of a unique and stable identity, instead, that individual identity is becoming increasingly fragmented in terms graduating from various identities that often contradict each other and that conform to different socio-cultural contexts surrounding the person, says the same author.

In this sense, the person takes more an identity that it is requested by a particular cultural system at a given time, than they want to conform by themselves, that is, it is taken more by circumstances than can conform itself as they say Mosquera \& Stobäus (1984), to explain in particular the adolescent identity building conditions in early adult life, until near the 30 - 35 years of chronological age.

Laurenti \& de Barros (2000) understand that the identity cannot be considered innate to human beings, but it is much more a process of historical and social construction, that is, a uniqueness that is built, historically and socially, the individual's relationship with its like.

Jacques (1999) also has a similar understanding, which states that personal identity is the result of construction in a given historical and social context in which the subject is inserted, but does not occur passively, since this context, while influencing the individual identity, by virtue of its ownership, is also influenced by the person in constant construction.

Mosquera \& Stobäus (2014) comprehend that identity is a process, not a product. According to them, the construction of identity occurs throughout the life of the subject, from social and cultural influences, and it is from it that we can recognize ourselves. The identity construction that each one makes of himself is not neutral, but it is a continuum of values, resulting from the ability of human beings to be dynamic, constantly (re)construction of his speeches and actions, their experiences, way of understanding the world with many possibilities, interests and values. This more dialectical and procedural design is because none of these aspects is static, but all are constantly changing, influenced by the social environment and at the same time influencing it.

In Positive Psychology, we will focus on the process of healthy identity. In this perspective, what would be the healthy identity then? For this question can be best answered, it would be necessary before we discuss a little about the welfare.

According Paludo \& Koller (2007), the Positive Psychology, studies on welfare are included in the investigations focused on the subjective experience of the person. According to the authors, Positive Psychology seeks to understand how factors such as virtues, skills, resilience contexts, finally, as positive experiences influence the 
subjective well-being of the person and the context of which it is inserted and acts.

Siqueira \& Padovan (2008) studied on the subjective well-being, commented that, so that you can your understanding in bias of Positive Psychology, there must be an understanding of factors that strengthen the person fighting adversity of his life, trying to understand those factors that promote more positive experiences and emotions, coping and overcoming.

In research on welfare, they were found two categories: the well-being subjective and the well-being psychological.

For Siqueira \& Padovan (2008), subjective well-being is considered an important category in Positive Psychology. It is the result of more cognitive self-assessments (and subjective-affective and social course) and selfanalysis that the person is on their positive and negative experiences throughout his life. Also point out that these cognitive assessments refer to the conceptions that each have about what can be the quality of your own life. Thus, it is different from thought quality of life more objectively, as defined by WHO, it would be limited to measurable factors like housing, resources, physical environment, among others. In more subjective perspective, so that there is an assessment of quality of life, it is necessary to consider the perceptions, ideas, and beliefs, opinions of each person in their social and cultural contexts.

To differentiate these two categories, Siqueira \& Padovan (2008) argue that while the subjective well-being is based on satisfaction ratings with life, in the comparison between the positive and negative endearment that reveal (times of) happiness, psychological well-being is based in psychological theories of human development, scaled in capacities to face at the constant challenges of life. According to Machado \& Bandeira (2012), the concept of psychological well-being has emerged as a criticism of subjective well-being. The author states that the latter concept was considered fragile, because it is based on a focused welfare structure only to the experiences of positive and negative endearments, disregarding the ontology of the subject.

Rounding out the psychological well-being includes the following categories: self-acceptance, positive relationships with others, autonomy, environmental, life purpose and personal growth, as Siqueira \& Padovan (2008).

Diener, Lucas, \& Oishi (2009) claim that cultural differences interfere in subjective well-being. For example, research shows that aspects such as self-esteem and extraversion are associated with little satisfaction and pleasurable affection in collectivist cultures, unlike what occurs in more individualistic cultures.

Aspects such as the basic needs, beliefs, values, goals, possessions and livelihoods, among others, influence the perception of well-being that the person performs. These and other demographic variables have different consequences in different cultures. Therefore, cross-cultural research promotes a fuller understanding of the relationship between environmental conditions and subjective well-being, put Diener, Lucas, \& Oishi (2009); Naiff, Ferreira, \& Naiff (2013).

A healthy identity, then contemplate the subjective well-being and personal psychological, with repercussions on their self-image, self-esteem and self-realization. But how would occur these impacts?

By studying self-esteem in adolescents, Lettnin, Dohms, Mendes, Stobäus, \& Mosquera (2015) understood that self-image as the person if you see yourself as if it were a self-portrait, and self-esteem, you as the person enjoys, like yourself. For them, these two constructs are interconnected and are influenced by other two variables: how the person sees and talks about his own person, through expressions of opinions received from others as social peers; and how she thinks others perceive, more to reactions perceptions to what they say and do socially. They consider that these variables act in the development of self-concept, meaning that all social relations and experiences are central to the identity of the human being. The more realistic are his judgments and impressions, are closer to their self-image and self-esteem of reality, the more distorted more unreal will be both for more (exaggeration) and for less (slights).

The way a person perceives themselves, the image they have of themselves, the esteem, the value, the importance that it self-explained and efforts dedicated to the realization of their talents/skills/abilities and their desire/expectations/values impacting their well-being in a comprehensive manner when running and to be realized fully Mays, and therefore constituent elements of their identity, for impact in its constant (re)construction as a person.

Mosquera \& Stobäus (2008) consider that self-esteem and self-image are part of the identity process, leading the human being to a better and more realistic self-knowledge, the pursuit of self-realization. They say that everyone has the need to be valued positively and hence to develop their self-esteem more realistically because it is forged also socially, from the social value of experiences that the person is submitted and accepted in their in- 
terpersonal relationships. In this perspective, the authors integrate self-esteem, self-actualization and self-image in a dialectical relationship, constituting the identity process.

For Seligman (2004), the way a person prepares and organizes the work in relation to other aspects of your life is very important for the experience of well-being. It states that there are three types of directions of work: job, vocation and career. The first is satisfied with their salary each month for their work (or similar rewards, for example when "work" in an NGO), without the involvement of any other type of reinforcer or reward. The vocation makes the work itself is the trigger, the driver of achievement, regardless of other factors such as cash and/or promotion to a position of higher status or better paid. Finally, career relates to personal investment aimed at the professional growth, glimpsing the promotion, better pay and status.

Leite \& Gonçalves (2009) argue that job satisfaction generates satisfaction with life. According to the authors, the work offers a number of important benefits for the person's welfare. So it is in the work we have occupation for much of our daily time with goals and objectives to be accomplished and achieved in accordance with the office exercised, where we face challenges to be overcome. Moreover, it is also in the practice that we have opportunities for inclusion and social interaction, as well as financial income and the recognition of a social status. A healthy identity, then, would be the result of more positive repercussions arising from experiences of subjective well-being and psychological, through self-realization. But, to what extent can this be (self) controlled? You can not totally. Adversity, difficulties and frustrations are part of human life and are also reflected in the person's constitution. There is no way to stop them, but there is a way to face them and mitigate them in order to contribute to a healthier identity process. This is where resilience enters in the study of identity formation.

\section{Healthy Identity and Resilience}

Resilience as psychological construct, comes from research on the ability of a person or a group has to overcome the crisis. Thus, psychology has sought to understand the processes and conditions involved in this overcoming as Yunes (2003).

The concept of resilience is a broad concept, still under construction. Psychology is believed that resilience is the ability of the subject to present a positive adaptation despite adversity. Thus, adverse life circumstances that could cause maladjustment generate positive adaptations to Monteiro, \& Farias (2006).

Rooke (2015), on conducting a survey on the studies published in Brazil on resilience, noted that this construct does not have consensus on its definition and the empirical research carried out are not sufficient for more consistent conclusions in this area because large part of the work focuses found resilience at the individual level, adopting more often, qualitative methods, using data from a few participants.

According to de Sousa (2009), the investigations focused on the resilience are generated from the need to seek explanation for the needs of the individuals, groups and organizations of positive overcome crises and adversities of life. It defines resilience as the man's ability to persist through constant adaptations through strength and perseverance in the face of difficulties and obstacles that may arise in your life. Taboada, Legal, \& Machado (2006), from his studies on this topic, conceive that resilience is still a fragile construct and poorly defined as a concept. His research shows little consensus about what is and how resilience occurs. Three main thematic poles were found. 1) Resilience as a process of adaptation versus overcome; 2) Resilience as an inborn factor versus acquired factor; 3) Resilience as something circumstantial versus permanent feature. These poles are formed from the constitutions of the research findings, they now focus on the individual, sometimes in the group, but always focusing on the coping abilities before the situation(s) of risk(s), among other spots. Thus, the authors suggest that it is built better operational definition of the concept, more objective and detailed, specifying the research behaviors and skills related to resilience.

According to Slap (2001), resilience is defined by the interaction of four components: individual factors, environmental, life-long events, and protective factors. The interactions between these elements will constitute what the author called the resource bank. These funds will be used in the face of adversity, but depend on the person's ability to use it.

However, this resilience model lacks many more research to turn to understand the function of individual and environmental characteristics in the constitution of these resources.

In the opinion of Aznar-Farias \& Oliveira-Monteiro (2006), the protective factors (or called bank Slap resources), ponder the relationship between the risks experienced by the subject and its development by modifying their personal responses and interacting indirectly through its effects. Resilience, then, is not in fact to avoid ad- 
verse experience and risk, but it is as a protective factor against them, changing the person's reaction and its possible consequences.

Considering the understanding that resilience is a way of coping and resilience in adverse circumstances, when faced with frustrating situations and risks from their skills one can develop a different view of what appears to initially aversive.

We take here the example of children's literature to try to better understand the issue. The Pollyanna book, American writer Porter (1942: pp. 35-36), tells the story of a 11 year old poor, girl, she lost her father and mother, then has moved in with her aunt an unknown, rich and demanding, in a strange city. In his new environment, Pollyanna takes hers new life, which is fraught with adverse situations, playing the "game content", taught by her father while he was still alive, which is to always get something positive out of the most unpleasant situations. To illustrate the game's content here we bring a book excerpt:

-You are a bit strange girl. Is always happy with everything and everyone-noted the maid, remembering what had happened in the attic closet.

-It's part of the game, you know?-And the girl smiled.

-What game?

-The "game content".

-Who put this in your head, baby?

-My father. It's a beautiful game. Since I was a kid playing it. After I taught the ladies 'Help' and they also

liked.

-How do you play?-I wondered Nancy.-not understand a lot of games.

Pollyanna smiled and after a sigh, said:

-It all started because of some crutches that came in the donations box to the missionary.

-Crutches?-Marveled Nancy.

-That's it. I had asked a doll Dad and when the box arrived, there was only one pair of crutches for children. Thus it began.

-And where's the game?

-Well, the game comes down to find joy in whatever it is concluded Pollyannaseriously.-We start with the little crutches..

-And where is the joy-surprised Nancy.-FIND crutches instead of dolls...

-That's it and the girl clapped her hands with joy.-In the beginning I did not understand.

-Then, with calm, Daddy explained everything.-So, explain to me too.

-I was gay just because they did not need crutches-explained Pollyanna.-See how easy it is?

-Well, that's nonsense!-Exclaimed Nancy

-No nonsense. The game is beautiful. Since that day, when something bad happens, funniest is the game. Hard was when Dad died and I was alone with the ladies of the "Help"...

-And when he saw that ugly little room, no carpets, no frames, no grace? How was it?-Nancy asked.

-It was hard. I felt so alone! At that time I had no desire to "play". Just remember what I had so desired.

Then I remembered the mirror and my freckles and was cheerful. And the "frame" of the window made me

even happier. With a little effort, we like what we find and forget what we wanted to find.

In explaining the Nancy what makes her so happy, Pollyanna explains the game's content, and says that to play it, you just need to look for some kind of joy in any situation, such as when the character teaches Nancy a strategy to deal with the situations of suffering. Notice that this strategy does not prevent the child to recognize the difficult situations, but only to help address them.

The game content is a resource acquired by Pollyanna from the interaction and living with her father. This strategy helped the character to deal with circumstances such as the death of the father, the move to the house of the unknown aunt and many other situations that occur during the plot. Interestingly, with the game's content, she can transform the characters around her, including the rich and uncompromising aunt. Here is an example of resilience. While playing the game content, the girl develops a new look to the experienced adversity, seeking the satisfaction and well-being, even in difficulty and suffering, developing a healthy identity, a state with some happiness. Ralha-Simões (2001) considers that resilience is linked to the process of construction and reconstruction of personality over personal development. The author assumes that, similarly, the resilience consists of a protective core strength of personality, resulting in a constant psychological reconstruction of the subject before 
the middle of adversity.

In the case of Pollyanna, on becoming an orphan, and to moving to the house of the unknown aunt and there pass the consequent adversity of a different and strange environment, we observe the way of perception of situations is purposely modified game of strategy content and, from there, their conceptions of themselves, others and situations are also changed.

When searching resilience processes in adolescents involved in intervention projects, Rodrigues, Souza, \& Poletto (2015) emphasize that social programs can help as prevention strategies before risk behaviors of adolescents, such as drug abuse, delinquency, among others. Such interventions can also foster the development of a more positive and healthier identity. It was found in his research that the various factors of the different contexts and social relations of which teenagers are part may be important to the process of resilience. The authors also point out that it is of fundamental importance to consider the successes and failures are constant in the life of humankind and their beliefs and consequently their identity, are designed from these experiences.

The study of identity, as a healthy identity in the Positive Psychology approach has in the resilience, an important element to its research and understanding.

\section{Conclusion}

We have tried in this article to draw a possibility of identity study in the perspective of Positive Psychology. We note that, in the literature available to date, we do not have many theoretical and/or methodological proposals that address this demand. So, from a design of fluid, procedural and unfinished identity, consequent social and cultural experiences of the subject, we try to approach the concept of identity of some concepts in this theoretical model as subjective well-being, psychological, self-esteem, self-image, self-realization and resilience.

The dialectic of these concepts, the ontological, social and cultural character assigned to them and the impact on the constitution of the subject make the important elements for the study to the understanding of identity. However, as the Positive Psychology advocates the study of more positive aspects in human experiences, we understand that identity, which more theoretical look should be studied as more realistic and healthy identity, consequently the well-being of a person in constant construction.

We believe that these concepts are constituent aspects of identity, whether healthy or not, and that, therefore, are variables that must be considered and analyzed in psychological research about the construction of identity.

However, there still needs an elaboration of many discussions on this subject and practical research focused on the study of identity in Positive Psychology is performed by relating these concepts to foster and sustain or refute the ideas here defended.

\section{References}

Aznar-Farias, M., \& Oliveira-Monteiro, N. R. (2006). Reflexões sobre pró-socialidade, resiliência e psicologia positiva [Reflections on Pro-Sociability, Resilience and Positive Psychology]. Revista Brasileira Terapia Cognitiva, 2, 39-46.

de Sousa, C. (2009). Motivação, Resiliência e Educação: Perspectivas e futuro [Motivation, Resilience and Education: Prospects and Future]. Anais do II SIPASE—Seminário Internacional Pessoa Adulta, Saúde e Educação: Motivaçãoem Diferentes Cenários, Porto. http://w3.ualg.pt/ jfarinha/activ_docente/pda_mestR7/textos/MotivResilEduc.pdf

Diener, E., Lucas, R. E., \& Oishi, S. (2009). Subjective Well-Being. The Science of Happiness and Life Satisfaction. In: C. R. Snyder, \& S. J. Lopez (Eds.), Oxford Handbook of Positive Psychology. Oxford: Oxford University Press. http://dx.doi.org/10.1093/oxfordhb/9780195187243.013.0017

Hall, S. (2003). A identidade cultural na pós-modernidade [Cultural Identity in Postmodernity]. Rio de Janeiro: DP \& A.

Jacques, M. G. (1999). Identidade. In: M. G. Jacques, et al. (Eds.), Psicologia Social Contemporânea [Identity, Contemporary Social Psychology] (pp. 159-167). Rio de Janeiro: Vozes.

Laurenti, C., \& de Barros, M. N. F. (2000). Identidade: Questões conceituais e contextuais [Identity: Conceptual and Contextual Issues]. Revista de Psicologia Social e Institucional, 2, 25-37.

Leite, A. P. T. T., \& Gonçalves, S. M. M. (2009). O trabalho pode ser prazeroso: Contribuições da Psicologia Positiva [The Work Can Be Pleasurable: Positive Psychology Contributions]. Anais do XV Encontro Nacional da ABRAPSO, Maceió.

Lettnin, C. da C., Dohms, K. P., Mendes, A. R., Stobäus, C. D., \& Mosquera, J. J. M. (2015). Evaluating Self-Esteem Levels of Brazilian and Portuguese Adolescents. Psych, 6, 314-322.

Machado, W. L., \& Bandeira, D. R. (2012). Bem-estar psicológico: Definição, avaliação e principais correlatos [Psychological Well-Being: Definition, Evaluation and Main Related]. Estudos de Psicologia, 4, 587-595. 
http://dx.doi.org/10.1590/S0103-166X2012000400013

Mosquera, J. J. M., \& Stobäus, C. D. (1984). Educação para a Saúde. Desafios para sociedades em mudança [Health Education. Challenges for Changing Societies] (2nd ed.). Porto Alegre: D.C. Luzzatto.

Mosquera, J. J. M., \& Stobäus, C. D. (2008). O professor, personalidade saudável e relações interpessoais: Por uma educação da afetividade [The Teacher, Healthy Personality and Interpersonal Relations: For an Education of Affectivity. Beeing Teacher]. In: D. Enricone (ed.). Ser Professor (6th ed.). Porto Alegre: EdiPUCRS.

Mosquera, J. J. M., \& Stobäus, C. D. (2014). Positive Psychology and Emotional Schedule: Building Healthy Self-Construction. Psych, 5, 533-540.

Naiff, L. A. M., Ferreira, M. C., \& Naiff, D. G. (2013). M. Bem-estar profissional de professores de escolas públicas e privadas. Arquivos Brasileiros de Psicologia, 65, 288-303.

Paludo, S. S., \& Koller, S. (2007) Psicologia Positiva: Uma nova abordagem para antigas questões [Positive Psychology: A New Approach to Old Questions]. Paideia, 36, 9-20. www.scielo.br/pdf/paideia/v17n36/v17n36a02.pdf

Pires, J. G., Nunes, M. F. O., \& Nunes, C. H. S. S. (2015). Instrumentos Baseados em Psicologia Positiva no Brasil: Uma Revisão Sistemática [Brazilian Instruments Based on Positive Psychology: A Systematic Review]. Psico-USF, Bragança Paulista, 20, 287-295. www.scielo.br/pdf/pusf/v20n2/1413-8271-pusf-20-02-00287.pdf http://dx.doi.org/10.1590/1413-82712015200209

Porter, E. H. (1942). Pollyana. São Paulo: Cia Editora Nacional.

Ralha-Simões, H. (2001). Resiliência e Desenvolvimento Pessoal [Resilience and Personal Development]. In M. A. M. Yunes, H. Szymanski, A. M. S. Pereira, H. Ralha-Simões, \& M. A. C. D. Castro (Eds.), Resiliência e Educação [Resilience and Education] (2nd ed., pp. 95-113). São Paulo: Cortez.

Rodrigues, S. N., Souza, A. P. L., \& Poletto, M. (2015). Processos de resiliência fomentados por projetos de intervenção com adolescentes [Resilience Processes Fomented by Intervention Projects with Adolescents]. In N. A. Morais, \& R. M. Coimbra (Eds.), A resiliência em questão: Perspectiva teóricas, pesquisa e intervenção [Resilience in Question: Theoretical Perspective, Research and Intervention]. Porto Alegre: Artmed.

Rooke, M. S. (2015). Aspectos conceituais e metodológicos da resiliência psicológica: Uma análise da produção científica brasileira [Conceptual and Methodological Aspects of Psychological Resilience: An Analysis of Brazilian Scientific Production]. Estudos e Pesquisas em Psicologia, 15, 671-687.

www.e-publicacoes.uerj.br/index.php/revispsi/article/view/17665/13061 http://dx.doi.org/10.12957/epp.2015.17665

Seligman, M. (2004). Felicidade autêntica: Usando a nova Psicologia Positiva para a realização permanente [Authentic Happiness: Using the New Positive Psychology to the Permanent Realization]. Rio de Janeiro: Objectiva.

Siqueira, M. M. M., \& Padovan, V. A. R. (2008). Bases Teóricas de Bem-Estar Subjetivo, Bem-Estar Psicológico e Bem-Estar no Trabalho [Theoretical Basis of Subjective Well-Being, Psychological Well-Being and Well-Being at Work]. Psicologia: Teoria e Pesquisa, 24, 201-209.

http://www.scielo.br/scielo.php?pid=S0102-37722008000200010\&script=sci_abstract\&tlng=pt http://dx.doi.org/10.1590/S0102-37722008000200010

Slap, G. B. (2001). Current Concepts, Practical Applications and Resilience in the New Millenium. International Journal of Adolescent Medicine and Health, 13, 75-78. http://www.ncbi.nlm.nih.gov/pubmed/22912324

Taboada, N. G., Legal, E. J., \& Machado, N. (2006). Resiliência: Em busca de um conceito [Resilience: Looking for a Concept]. Revista Brasileira de Crescimento e Desenvolvimento Humano, 16, 104-113. http://pepsic.bvsalud.org/scielo.php?script=sci arttext\&pid=S0104-12822006000300012

Yunes, M. A. M. (2003). Psicologia positiva e resiliência: O foco no indivíduo e na família [Positive Psychology and Resilience: Focus on the Individual and Families]. Psicologia em Estudo, 8, 75-84.

http://www.scielo.br/pdf/pe/v8nspe/v8nesa10.pdf http://dx.doi.org/10.1590/S1413-73722003000300010 